\title{
Induction of estrogen receptor $\alpha-36$ expression by bone morphogenetic protein 2 in breast cancer cell lines
}

\author{
DINGDING WANG ${ }^{1}$, PEIDE HUANG ${ }^{2}$, BAOWEI ZHU ${ }^{2}$, LI SUN $^{2}$, QING HUANG $^{2}$ and JU WANG ${ }^{2}$ \\ ${ }^{1}$ Department of Biotechnology, Institute of Life Science and Biological Pharmacy, Guangdong Pharmaceutical University, \\ Guangzhou, Guangdong 510006; ${ }^{2}$ Guangdong Provincial Key Laboratory of Bio-engineering Medicine \\ (National Engineering Research Centre of Genetic Medicine), Guangzhou, Guangdong 510632, P.R. China
}

Received April 8, 2012; Accepted June 6, 2012

DOI: $10.3892 / \mathrm{mmr} .2012 .945$

\begin{abstract}
The expression of estrogen receptor- $\alpha(E R \alpha)$ is one of the most important diagnostic and prognostic factors of breast cancer. Recently, ER $\alpha-36$ has been identified as a novel variant of ER- $\alpha$. ER $\alpha-36$ lacks intrinsic transcription activity and mainly mediates non-genomic estrogen signaling. Bone morphogenetic proteins (BMPs) are recognized as key factors during the control of cell fate and cancer development. However, the correlation between BMP and the ER signaling pathway remains unclear. In this study, we show that BMP2, a member of the BMP family, is a novel inducer of ER $\alpha-36$ expression in breast cancer cells. As shown by western blot assays, the upregulation of ER $\alpha-36$ by BMP2 was significant. In MDA-MB-231 cells which are ER $\alpha$-66-negative, BMP2 was able to induce the expression of ER $\alpha-36$ in a dose-dependent manner, and the RNA interference assay indicated a correlation between BMP2 and ER $\alpha-36$ expression. BMP2 inhibited the growth of MCF-7 and MDA-MB-231 cells; however, the inhibitory effect was antagonized by tamoxifen, suggesting that the ER signal was involved. The growth of MDA-MB-231 cells was stimulated by $17-\beta$-estradiol (E2) after BMP2 induction, even though the cells were previously insensitive to E2. These results suggest that BMP2 induces ER $\alpha-36$ expression and alters tumor resistance to endocrine therapy by changing the expression profile of ERs.
\end{abstract}

\section{Introduction}

Members of the transforming growth factor (TGF)- $\beta$ family, including TGF- $\beta$, activin, nodal and bone morphogenetic proteins (BMPs), are multifunctional cytokines that regulate a wide range of cellular responses, such as cellular proliferation,

Correspondence to: Dr Ju Wang, Guangdong Provincial Key Laboratory of Bio-engineering Medicine (National Engineering Research Centre of Genetic Medicine), 601 Huangpu Ave. (West), Guangzhou, Guangdong 510632, P.R. China

E-mail: wang_ju1688@yahoo.cn

Key words: estrogen receptor- $\alpha$, estrogen receptor- $\alpha-36$, bone morphogenetic protein 2 , breast cancer cell adhesion and differentiation, haematopoiesis, inflammation, wound repair and skeletal development (1). BMPs were identified based on their ability to promote ectopic cartilage and bone formation (2). BMPs function through conserved type I and type II transmembrane receptors and Smad-dependent and -independent pathways, to regulate a range of biological processes in a highly context-dependent manner (1,3-5). Disruption of these pathways can lead to various diseases including cancer (6).

Estrogenic hormones regulate multiple activities, including cell proliferation and differentiation, in different types of cells. It is widely accepted that the hormone-occupied estrogen receptor (ER) functions as a versatile transcription factor to either activate or repress gene expressions (7). These effects of estrogen on transcriptional regulation involve both the direct interaction of ER with DNA encoded estrogen response elements (EREs) and the indirect tethering of ER to DNA through protein-protein interactions $(8,9)$. In addition to these nuclear events, estrogen is capable of evoking rapid, membrane-initiated signaling events, such as the release of calcium, secretion of prolactin, generation of nitric oxide, regulation of PI3K/Akt and the activation of the MAPK pathway (10-12). Estrogen can influence these effects in a variety of cell types (13), with the exact response dependent on the nature of the target cell.

The ER signaling pathway plays a pivotal role in the development of different types of breast cancer (14). Two types of ERs have been identified, ER $\alpha$ and ER $\beta$, both of which have many mRNA splice variants (15). For example, there are 3 types of $\mathrm{ER} \alpha$ isoforms identified: 66-KD, 46-KD and 36-KD (16). Usually, if a cell line expresses ER $\alpha-66$ (e.g., MCF-7 cells) it is considered ER $\alpha$-positive; if a cell line does not express ER $\alpha-66$ (e.g., MDA-MB-231 cells) it is termed ER $\alpha$-negative.

Endocrine therapy is effective in approximately one-third of all breast cancers, although up to $80 \%$ of these express both estrogen and progesterone receptors (17). Unfortunately, most breast cancer cells acquire resistance due to the use of steroid hormones in the process of endocrine treatment for controlling the growth of cancer cells (18). In order to understand the effects of ERs on the development of breast cancer, we wished to explore the correlation between the ER signaling pathway and other pathways, such as the Wnt/wingless, receptor tyrosine kinase, JAK/STAT and the BMP signaling pathways, which are included among the conserved pathways that control the fate of cells $(19,20)$. 
In this study, we report for the first time that BMP2 induces the expression of ER $\alpha-36$, but not ER $\alpha-66$, in MDA-MB-231 and MCF-7 breast cancer cell lines. The results from our study indicate that BMP2 alters the expression profile of ER $\alpha$ and thus, has the potential to alter the response of breast cancer cells to endocrine therapy.

\section{Materials and methods}

Cell lines and antibodies. The human breast cancer cell lines, MDA-MB-231 (ER-negative) and MCF-7 (ER-positive), were obtained from the American Type Culture Collection (ATCC). All cells were passaged for a period of $<6$ months subsequent to resuscitation, and cultured using the protocol provided by ATCC. The sera and media were purchased from Invitrogen and ATCC, whereas anti- $\beta$-actin, anti-ER $\alpha-66$ and anti-ER $\beta$ antibodies were from Cell Signaling Technology. HRP-goat anti-rabbit conjugate and HRP-goat anti-mouse conjugate were purchased from Santa Cruz Biotechnology,.

Quantitative RT-PCR. MCF-7 and MDA-MB-231 breast cancer cells were plated in $10-\mathrm{cm}$ dishes, and subsequently treated with BMP2 $(20 \mathrm{ng} / \mathrm{ml})$ for 0,24 and $48 \mathrm{~h}$. Total RNA was extracted using TRIzol reagent, and cDNA was prepared using SuperScript II Reverse Transcriptase (Invitrogen). Quantitative RT-PCR was performed using the IQ SYBRGreen Mix in an iCycler PCR machine (Bio-Rad), using $1 \mu \mathrm{l}$ of cDNA in triplicate. Primers used are included in Table I.

Specific antibody for ER $\alpha-36$. The antigenicity of the specific C-terminal amino acid sequence of ER $\alpha-36$ was analyzed using the Onastar software. The IFGNKWFPRV sequence was selected and named IV10. This amino acid sequence was made using solid phase chemical synthesis and coupled by KLH. The specific antibody against IV10 was obtained from the antiserum of rabbits and purified by Protein A affinity chromatography.

Western blot analysis. MCF-7 and MDA-MB-231 breast cancer cells were incubated with $20 \mathrm{ng} / \mathrm{ml} \mathrm{BMP} 2$ for 24 and $48 \mathrm{~h}$. For western blot analyses, cells were disrupted by incubation at $4^{\circ} \mathrm{C}$ for $15 \mathrm{~min}$ in cell lysis solution (UpState) containing protease inhibitor cocktail (Roche). The protein concentration was quantified using a $\mathrm{BCA}^{\mathrm{TM}}$ Protein Assay kit (Pierce). Equal amounts of protein $(20 \mu \mathrm{g})$ were subjected to $12 \%$ SDS-PAGE and western blot analysis, as described previously (21). Immunoreactive bands were visualised by an enhanced chemiluminescence reaction kit (Thermo Fisher Scientific).

RNA interference. The sense strands of BMPR1a-siRNA and BMPR1b-siRNA were purchased from Dharmacon, Inc. MDA-MB-231 cells were seeded into 6-well plates, grown to 40-60\% confluence and then transfected with siRNAs for $4 \mathrm{~h}$ using Lipofectamine 2000 (Invitrogen). The cells were allocated to 3 groups: control group, BMP2 group and si-BMPR1a+ si-BMPR 1b + BMP2 group. The dosage of BMP2 was $20 \mathrm{ng} / \mathrm{ml}$. The protein levels were analyzed by western blot analysis.

Cell proliferation assay. For the proliferation assay with recombinant human BMP2 (R\&D Systems, Minneapolis,
MN, USA), MCF-7 and MDA-MB-231 cells were cultured in 96-well plates (approximately 5,000 cells per well) for $24 \mathrm{~h}$, respectively. Cells were then serum-starved for $24 \mathrm{~h}$ in DMEM with $1 \%$ FBS. The experiment included a control group and a BMP2 group $(2.5,5,10,20$ or $30 \mathrm{ng} / \mathrm{ml})$. After $48 \mathrm{~h}$ of induction by BMP2, cell growth was measured by an MTT assay.

Tamoxifen citrate (Sigma) was used to identify the correlation between BMP2 and 17- $\beta$-estradiol (E2) (Sigma). Cells were plated in 96-well plates (approximately 5,000 cells/well) for $24 \mathrm{~h}$ in phenol red-free DMEM containing 2\% FBS that had been incubated with dextran-coated charcoal to remove endogenous steroids (dialyzed fetal bovine serum, PAA Laboratories). Cells were then incubated with BMP2 $(20 \mathrm{ng} / \mathrm{ml})$, E2 $(0.01 \mu \mathrm{M})$ and tamoxifen citrate (Tam, $0.01 \mu \mathrm{M})$ for $48 \mathrm{~h}$. The experiment included a control group, a BMP2 group (20 ng/ml), an E2 group, a Tam group, a E2 + BMP2 group and a Tam + BMP2 group. The MTT assay was used to determine the relative cell number. Absorbance was recorded at $570 \mathrm{~nm}$ in a spectrophotometer (Spectronic 1001, Bausch \& Lomb). The mean value of 5 wells was calculated and each experiment was repeated 3 times.

Statistical analysis. Statistical analysis was carried out using the Statistical Package for Social Sciences 13.0 (SPSS). Data are presented as the means \pm SEM. Statistical significance was determined by a one-way analysis of variance or the t-test. P-values $<0.05$ were considered to indicate statistically significant differences.

\section{Results}

$B M P 2$ alters the expression of genes in $M C F-7$ and $M D A-M B-$ 231 cells. To understand the effect of BMP2 on the BMP and ER signaling pathway in MCF-7 and MDA-MB-231 cells, the changes in the expression of key genes, such as BMPR1a, BMPR1b, BMPR2, ER $\alpha$ and ER $\beta$, were examined using quantitative RT-PCR following the addition of $20 \mathrm{ng} / \mathrm{ml} \mathrm{BMP} 2$. Interestingly, we found that treatment with BMP2 upregulated the expression of ER $\alpha$ almost 7-fold in MCF-7 and 4-fold in MDA-MB-231 cells. Since ER $\alpha$ had at least 3 types of identified splicing variants (ER $\alpha-66, E R \alpha-46$ and $E R \alpha-36)$, we designed specific primers for ER $\alpha-66$ and ER $\alpha-36$ and examined their specific expression. Genomic organization of the human ER $\alpha-66 / 36$ gene and the positions of the primer pairs were shown in Fig. 1. The results shown in Fig. 2 indicated that the upregulation of ER $\alpha-36$ by BMP 2 was sustained from 24 to $48 \mathrm{~h}$ in MCF-7 cells and was the highest at $48 \mathrm{~h}$ in MDA-MB-231 cells. ER $\alpha-66$ expressed in MCF-7 cells was slightly higher at $24 \mathrm{~h}$. By contrast, the expression of ER $\beta$ was not changed after the addition of BMP2 (Fig. 2) in either of the cell lines.

BMP2 induces the expression of ER $\alpha-36$ in MCF-7 and $M D A-M B-231$ cells. Western blot analysis was used to evaluate the protein levels of ER $\alpha$ in BMP2-treated breast cancer cells. Since the C-terminal of ER $\alpha-36$ was unique, we raised antibodies against a synthetic peptide antigen (IV10) corresponding to the C-terminal 10 aa of $h E R \alpha-36$. Its specificity was determined in MDA-MB-231 cells (Fig. 3A). We observed that ER $\alpha-36$ was significantly upregulated by BMP2 in 
Table I. Primers used for real-time PCR.

Genes

Primer sequences (F, forward; $\mathrm{R}$, reverse)

\begin{tabular}{lll}
\hline ER $\alpha$ & F: AAGTATTCAAGGACATAACG & R: TATCCCACCTTTCATCAT \\
ER $\alpha-66$ & F: GGTGCCCTACTACCTGGAGA & R: TCTGAATTTGGCCTGTAGAATG \\
ER $\alpha-36$ & F: GACAGGAACCAGGGAAAA & R: TCTACATGTGAGATACCAGA \\
ER $\beta$ & F: TCATGAATTACAGCATTCCC & R: ATGAAGTGAGCATCCCTCTT \\
BMPR1b & F: AATGCCACCATTGTCCA & R: CTAGGCAACCAGAAGTGACCACAG \\
BMPR1a & F: AGTGTCTCCAGTCAAGCTCTGGGTA & R: CCATCTCTGCTGCTGCGCTCATTTA \\
BMPR2 & F: TGCAGATGGACGCATGGAA & R: CGGCAAGAGCTTACCCAGTCA \\
p21 & F: TGAGCCGCGACTGTGATG & R: GTCTCGGTGACAAAGTCGAAGTT \\
\hline
\end{tabular}

ER, estrogen receptor; BMP, bone morphogenetic protein receptor.

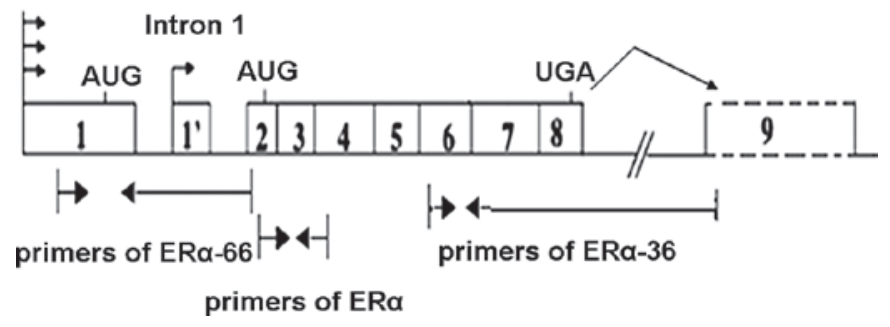

Figure 1. Genomic organization of the human hER $\alpha-66 / 36$ gene, and the positions of the 3 primer pairs used in this study. The locations of the multiple promoters of hER $\alpha-66$ are shown as arrows. The translation start and stop codons are indicated as AUG and UGA. The common exons are shown as numbered open boxes (solid line). The extra exon that is beyond the 8 exons, found in the $\mathrm{hER} \alpha-36$ gene, is numbered as 9 in the open box (broken line). Intron 1 is also shown with exon 1 in the open box. The 3 pairs of primers were chosen to span an intron within the genomic sequence.

MDA-MB-231 cells, which were ER $\alpha-66$-negative (Fig. 3B). We also found that BMP2 induced the expression of ER $\alpha-36$, but not ER $\alpha-66$ in MCF-7 cells (Fig. 3C). The expression of $\mathrm{ER} \beta$ did not change in either of the cell lines.

$B M P 2$ regulates the expression of the ER $\alpha-36$ protein. To assess the correlation between BMP2 and ER $\alpha-36$, an additional investigation was carried out on MDA-MB-231 cells (ER $\alpha-66$-negative). BMP2 induced the expression of $E R \alpha-36$ in a dose-dependent manner, which was inhibited by the BMP2 antagonist, noggin (Fig. 4A). In addition, the RNA interference assay indicated that BMP2 was associated with ER $\alpha-36$ expression. When the BMP2 signaling pathway was silenced by si-BMPR la and si-BMPR1b, the ER $\alpha-36$ induction was eradicated (Fig. 4B). Hence, it is possible that crosstalk exists between BMP2 and ER $\alpha-36$.

BMP2 inhibits the growth of MCF-7 and MDA-MB-231 cells. MTT assays revealed that the proliferation of MCF-7 and MDA-MB-231 cells was significantly inhibited by BMP2 (2.5, 5,20 or $30 \mathrm{ng} / \mathrm{ml}$ ) for 2 days. BMP-2 was effective in inhibiting the growth of the MCF-7 cells when its dose was 5-30 ng/ml, but the most effective dose was $20 \mathrm{ng} / \mathrm{ml}$. A similar effect of BMP-2 was observed in the MDA-MB-231 cells; however, its inhibitory effect on cell proliferation was more prominent in MCF-7 than in MDA-MB-231 cells (Fig. 5A).
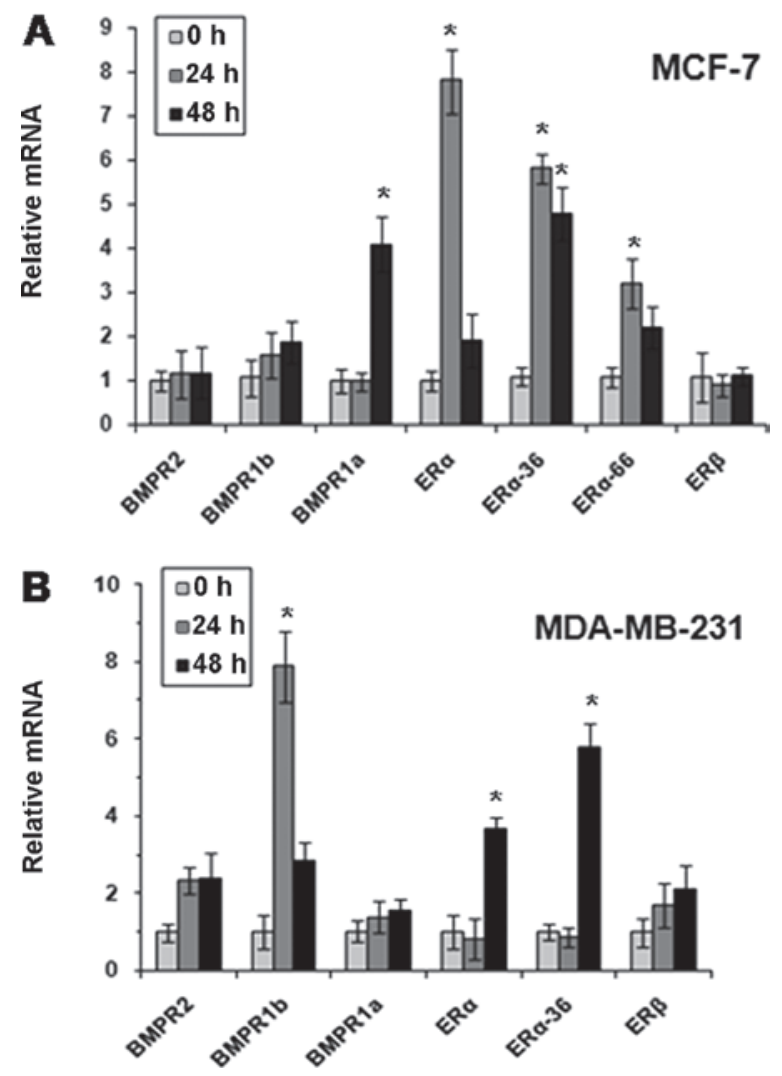

Figure 2. Changes in ER $\alpha$ (including the 3 isoforms: 66, 46 and 36KD), ER $\alpha-66$ and ER $\alpha-36$ mRNA expression in MCF-7 and MDA-MB-231 cells after induced by BMP2 (20 ng/ml). (A) MCF-7 cells treated with BMP2. The expression of ER $\alpha$ was highest at $24 \mathrm{~h}$, but dropped at $48 \mathrm{~h}$. The expression of ER $\alpha-36$ was upregulated constantly from 24 to 48 h. (B) MDA-MB-231 cells treated with BMP2. The expression of ER $\alpha$ and ER $\alpha-36$ was highest at $48 \mathrm{~h}$, and ER $\alpha-36$ was upregulated 6 -fold at $48 \mathrm{~h}$. The value of $2^{-\Delta \Delta \mathrm{Ct}}$ represents the expression of the ER $\alpha, \mathrm{ER} \alpha-66, \mathrm{ER} \alpha-36, \mathrm{BMPR} 1 \mathrm{a}, \mathrm{BMPR} 1 \mathrm{~b}$ and BMPR2 genes in BMP2-treated cells normalized to $\beta$-actin, relative to the normalized expression of ER $\alpha, \mathrm{ER} \alpha-66, \mathrm{ER} \alpha-36, \mathrm{BMPR} 1 \mathrm{a}, \mathrm{BMPR} 1 \mathrm{~b}$ and BMPR2 genes in the control cells, respectively. Results of 3 independent experiments were averaged and the mean values \pm SEM are shown. ${ }^{*} \mathrm{p}<0.05$ compared to the $0 \mathrm{~h}$ group.

MDA-MB-231 cells were not sensitive to E2 and tamoxifen treatment as shown in Fig. 2B. However, the BMP2 inhibition of MDA-MB-231 cells was antagonised when E2 or tamoxifen 
A

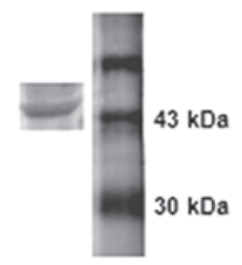

B
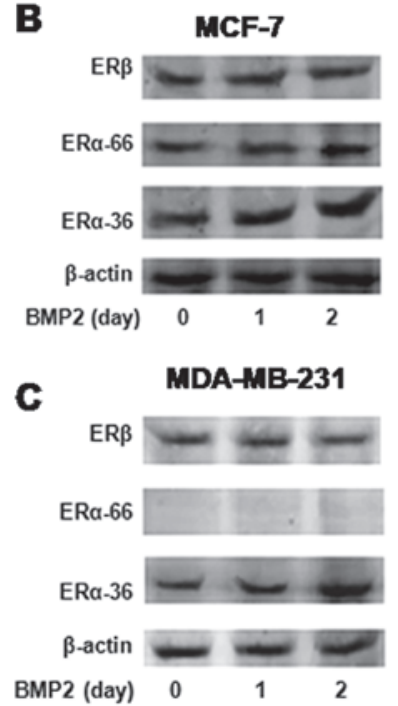
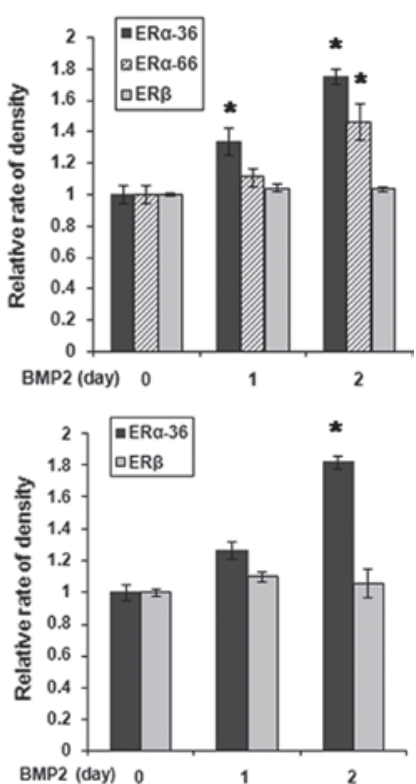

cells as shown by western blot analysis. (A) The expression of ER $\alpha-36$ in MDA MB-231 cells indicating that the antibody against ER $\alpha-36$ was specific. (B) The expression of ER $\alpha-36$ significantly increased afterinduction by BMP $2(20 \mathrm{ng} / \mathrm{ml})$ in MCF-7 cell lines. The same effect was observed for ER $\alpha-66$, but the variation was weaker than ER $\alpha-36$. There was no change in the expression of ER $\beta$. $\beta$-actin was used as the control. (C) ER $\alpha-36$ was upregulated prominently in MDA-MB-231 cells subsequent to treatment with BMP2, and ER $\alpha-66$ was not expressed in MDA-MB-231 cells. ER $\beta$ expression was not changed. Each bar represents the mean value $\pm \operatorname{SEM}(n=3)$. ${ }^{*} \mathrm{p}<0.05$ compared to the $0 \mathrm{~h}$ group.

were added. E2 promoted the multiplication of MCF-7 cells, while tamoxifen restrained their growth (Fig. 5B). The inhibitory effect of BMP2 was, however, counteracted by tamoxifen. We also observed that MCF-7 cells treated with BMP2 were insensitive to tamoxifen treatment (Fig. 5C). The results from our study were consistent with those from previous reports stating that tamoxifen strongly inhibits cell proliferation in the MCF-7 cells. The constitutive overexpression of recombinant ER $\alpha-36$, however, demonstrated insensitivity to tamoxifen treatment (22). Since the MDA-MB-231 cells were ER $\alpha-66$ negative and ER $\alpha$-36-positive following BMP2 treatment, we hypothesized that the breast cancer cells became sensitive to E2 and resistant to tamoxifen following the induction of $\mathrm{ER} \alpha-36$ by BMP2.

\section{Discussion}

In the present study, we identified that BMP2 induced the expression of ER $\alpha-36$ in MDA-MB-231 and MCF-7 breast cancer cells. A previous study on the induction of ER $\alpha$ and ER $\beta$ in granulosa cells by activin also showed that BMP-2 increased ER $\alpha$ mRNA levels by approximately $50 \%$ (23), consistent with our results.

Wang et al (21) reported that ER $\alpha-36$ lacks both transcriptional activation domains of $\mathrm{ER} \alpha-66$, retains portions

A

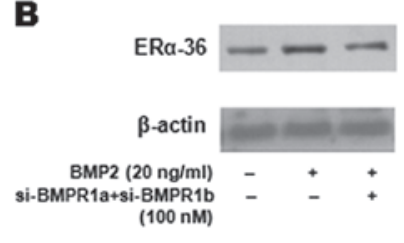

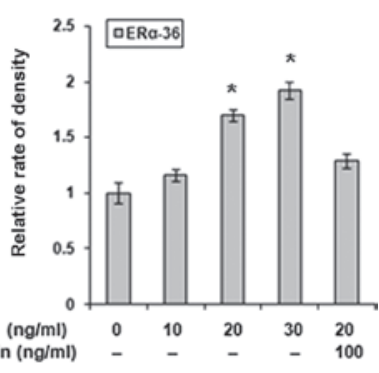

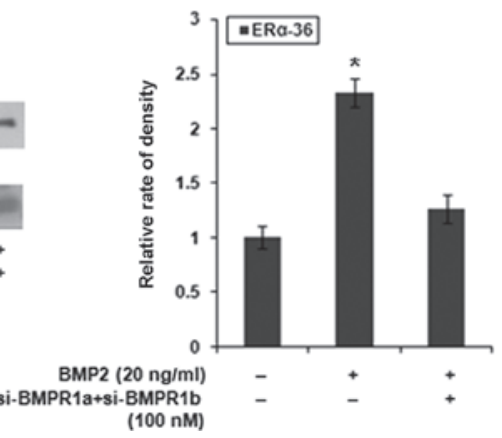

Figure 4. Western blot and RNA interference assays were used to examine the induction of ER $\alpha-36$ regulated by BMP2 in MDA-MB-231 cells. (A) The expression of ER $\alpha-36$ induced by BMP2 was dose-dependent and was inhibited by its antagonist (noggin). Each bar represents the mean value \pm SEM $(\mathrm{n}=3) .{ }^{*} \mathrm{p}<0.05$ compared to the $0 \mathrm{~h}$ group without noggin, (B) The expression of ER $\alpha-36$ was upregulated almost 2.5 -fold when BMP2 was added. This effect was reversed when the BMP2 signaling pathway was silenced. Each bar represents the mean value \pm SEM $(n=3)$. $" p<0.05$ compared to the control group.
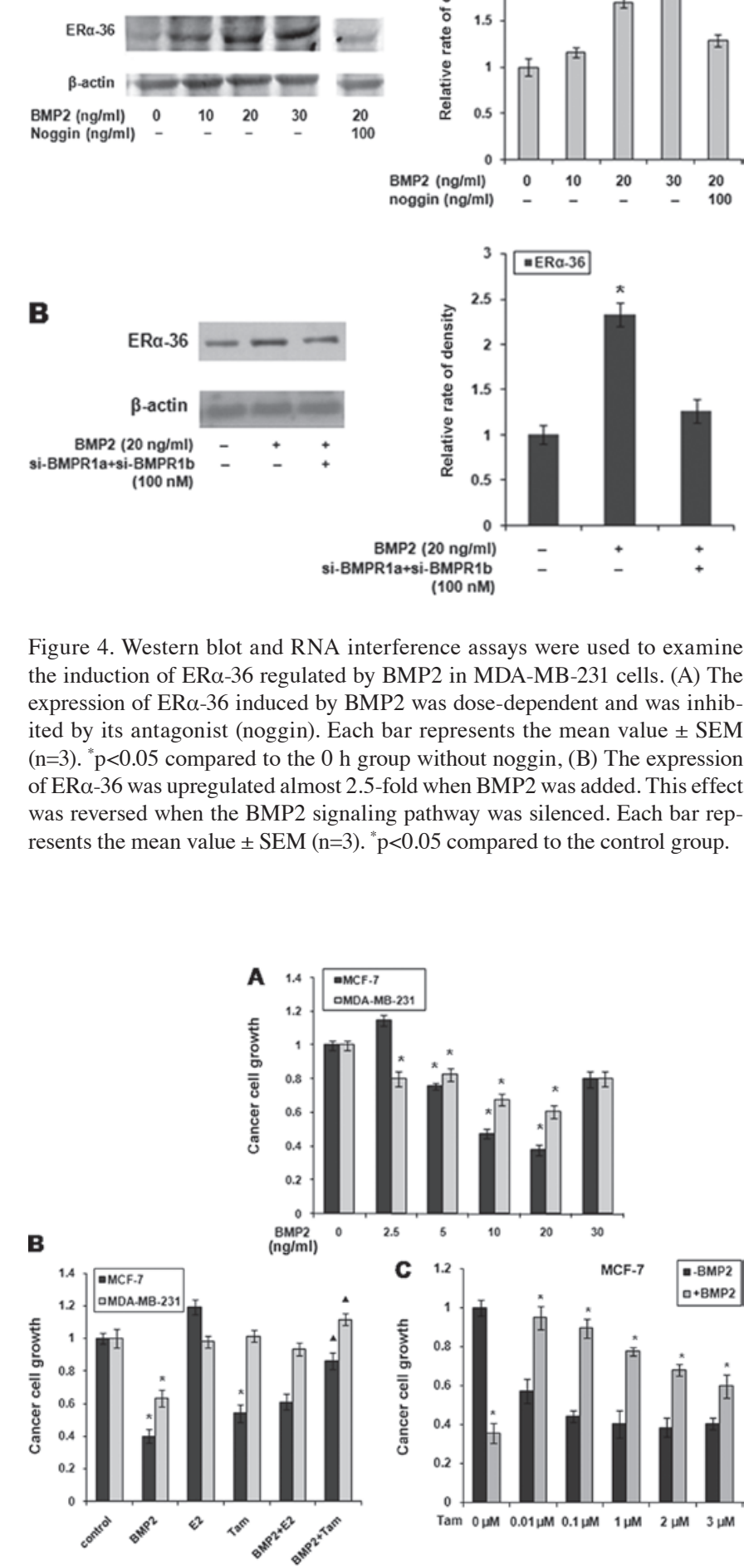

Figure 5. The effects of BMP2, 17- $\beta$-estradiol (E2) and tamoxifen citrate (Tam) on the proliferation of MCF-7 and MDA-MB-231 cells by MTT assay. (A) Cells treated with $2.5,5,10,20$ or $30 \mathrm{ng} / \mathrm{ml}$ recombinant human BMP2 (rhBMP2) for 2 days. Results of 3 independent experiments were averaged and the mean values \pm SEM are shown. ${ }^{*} \mathrm{p}<0.05$ compared to the $0 \mathrm{ng} / \mathrm{ml}$ group. (B) Cells treated with BMP2 $(20 \mathrm{ng} / \mathrm{ml})$, E2 $(0.01 \mu \mathrm{M})$, Tam $(0.01 \mu \mathrm{M})$, and the indicated combinations for 2 days. The growth of cells was inhibited differently. Results of 3 independent experiments were averaged and the mean values \pm SEM are shown. ${ }^{*} \mathrm{p}<0.05$ compared to the control group, ${ }^{\star} \mathrm{p}<0.05$ compared to the BMP2 group. (C) MCF-7 cells were treated with different concentrations of tamoxifen containing BMP2 or without BMP2 in medium for $48 \mathrm{~h}$. MTT assay was performed. Results of 3 independent experiments were averaged and the mean values \pm SEM are shown. ${ }^{*} p<0.05$ compared to the groups without $\mathrm{E} 2$. 
of the DNA-binding domain, the partial dimerization and ligand-binding domains, and possesses a unique 27 amino acid domain that replaces the last 138 amino acid of ER $\alpha-66$. Moreover, ER $\alpha-36$ can inhibit the transactivation of both ER $\alpha-66$ and ER $\beta$, stimulate the MAPK signaling pathway and induce cell growth in breast cancer cell lines. Considering all the above information, the effect of ER $\alpha-36$ on the growth inhibition induced by BMP2 is complicated, thus additional investigation is required to clarify it.

An issue that scientists and clinical physicians should address is why endocrine therapy is effective on some kinds of breast cancers, but not on others. Recent studies have indicated that the efficacy of endocrine therapy cannot be simply explained by the expression levels of ER $\alpha$, but may be determined by the expression profiles of both $\mathrm{ER} \alpha$ and $\mathrm{ER} \beta$, as well as their various splice variants $(14,21,24,25)$. Furthermore, to understand the meaning of the demonstrated change in ER $\alpha-36$ expression induced by BMP2 in breast cancer cells, additional research should be carried out to determine whether the ER $\alpha-36$ reported in the present study is the same as that reported by Wang et al (21).

Anti-estrogen compounds are widely used for the treatment of osteoporosis, breast cancer and other diseases. Smad4, a common signal transducer in the BMP/TGF- $\beta$ signaling pathway, functions as a transcriptional co-repressor for human $\mathrm{ER} \alpha(26)$. Estrogen and glucocorticoid interact in osteoblastic differentiation regulated by BMP and TNF- $\alpha$ in mouse myoblastic $\mathrm{C} 2 \mathrm{C} 12$ cells. The expression of ERs, $\mathrm{ER} \alpha$ and $\mathrm{ER} \beta$, as well as the glucocorticoid receptor (GCR) has been shown to be significantly increased by BMP-2 treatment, regardless of the presence of estradiol and dexamethasone (27). ER $\alpha$, BMP-2 and BMP-4 expressions have been found to correlate temporarily, during the development of the osteoblast phenotype in early fibroblastic stem cells (28). These observations indicate that the ER pathway is closely associated with the BMP pathway during bone development and remodeling. In previous studies, BMP-6 expression was determined to be activated by estrogen in the MCF-7 breast cancer cell line (29). It was also reported that BMP-2-induced the activation of Smad activity and that BMP-2-mediated gene expression was suppressed by $\mathrm{E} 2$ in breast cancer cells via direct physical interactions between Smads and ER (30). Therefore, the crosstalk between the BMP and ER pathways may play a role in tumor differentiation and metastasis. It is reported in this study, for the first time, that BMP2 can induce the expression of ER $\alpha-36$ in MCF-7 and MDA-MB-231 cells. This study provides new insights into the BMP2 function in breast cancer cells. Understanding the crosstalk of BMP2 and ER signaling pathways will increase our understanding of the mechanisms of many diseases, in addition to cancer, that are important to human health.

\section{Acknowledgements}

The authors would like to thank Miss Li Yueqin for the technical support and Drs Li Hongjian and Cai Dongqing for having discussed the key issues in this study. The present study was supported by grants from the Guangzhou Scientific and Technical Project (33107005) and by the Foundation for Distinguished Young Talents in Higher Education of Guangdong, China (LYM11080).

\section{References}

1. Miyazono K, Kamiya Y and Morikawa M: Bone morphogenetic protein receptors and signal transduction. J Biochem 147: 35-51, 2010.

2. Wozney JM, Rosen V, Celeste AJ, Mitsock LM, Whitters MJ, Kriz RW, Hewick RM and Wang EA: Novel regulators of bone formation: molecular clones and activities. Science 242: 1528-1534, 1988 .

3. Attisano L and Wrana JL: Signal transduction by the TGF-beta superfamily. Science 296: 1646-1647, 2002.

4. Lee J, Son MJ, Woolard K, Donin NM, Li A, Cheng CH, Kotliarova S, Kotliarov Y, Walling J, Ahn S, et al: Epigeneticmediated dysfunction of the bone morphogenetic protein pathway inhibits differentiation of glioblastoma-initiating cells. Cancer Cell 13: 69-80, 2008.

5. Varga AC and Wrana JL: The disparate role of BMP in stem cell biology. Oncogene 24: 5713-5721, 2005.

6. Farnsworth RH, Karnezis T, Shayan R, Matsumoto M, Nowell CJ, Achen MG and Stacker SA: A role for bone morphogenetic protein-4 in lymph node vascular remodeling and primary tumor growth. Cancer Res 71: 6547-6557, 2011.

7. Katzenellenbogen BS and Katzenellenbogen JA: Estrogen receptor transcription and transactivation: Estrogen receptor alpha and estrogen receptor beta: regulation by selective estrogen receptor modulators and importance in breast cancer. Breast Cancer Res 2: 335-344, 2000.

8. Glidewell-Kenney C, Weiss J, Lee EJ, Pillai S, Ishikawa T, Ariazi EA and Jameson JL: ERE-independent ERalpha target genes differentially expressed in human breast tumors. Mol Cell Endocrinol 245: 53-59, 2005

9. Holmes KA, Hurtado A, Brown GD, Launchbury R, RossInnes CS, Hadfield J, Odom DT and Carroll JS: Transducin-like enhancer protein 1 mediates estrogen receptor binding and transcriptional activity in breast cancer cells. Proc Natl Acad Sci USA 109: 2748-2753, 2012.

10. Vasudevan N, Kow LM and Pfaff DW: Early membrane estrogenic effects required for full expression of slower genomic actions in a nerve cell line. Proc Natl Acad Sci USA 98: 12267-12271, 2001.

11. Baselga J, Semiglazov V, van Dam P, Manikhas A, Bellet M, Mayordomo J, Campone M, Kubista E, Greil R, Bianchi G, et al: Phase II randomized study of neoadjuvant everolimus plus letrozole compared with placebo plus letrozole in patients with estrogen receptor-positive breast cancer. J Clin Oncol 27: 2630-2637, 2009.

12. Edwards DP: Regulation of signal transduction pathways by estrogen and progesterone. Annu Rev Physiol 67: 335-376, 2005.

13. Liu H, Qiu J, Li N, Chen T, Cao X: Human phosphatidylethanolamine-binding protein 4 promotes transactivation of estrogen receptor alpha (ERalpha) in human cancer cells by inhibiting proteasome-dependent ERalpha degradation via association with Src. J Biol Chem 285: 21934-21942, 2010.

14. Thomas C, Gustafsson JA: The different roles of ER subtypes in cancer biology and therapy. Nat Rev Cancer 11: 597-608, 2011.

15. Herynk MH and Fuqua SA: Estrogen receptor mutations in human disease. Endocr Rev 25: 869-898, 2004.

16. Wang Z, Zhang X, Shen P, Loggie BW, Chang Y and Deuel TF: Identification, cloning, and expression of human estrogen receptor-alpha36, a novel variant of human estrogen receptoralpha66. Biochem Biophys Res Commun 336: 1023-1027, 2005.

17. Osborne CK: Tamoxifen in the treatment of breast cancer. N Engl J Med 339: 1609-1618, 1998.

18. Miller TW, Balko JM and Arteaga CL: Phosphatidylinositol 3 -kinase and antiestrogen resistance in breast cancer. J Clin Oncol 29: 4452-4461, 2011.

19. Ho CC and Bernard DJ: Bone morphogenetic protein 2 acts via inhibitor of DNA binding proteins to synergistically regulate follicle-stimulating hormone $\beta$ transcription with activin $\mathrm{A}$. Endocrinology 151: 3445-3453, 2010.

20. ten Dijke P, Korchynskyi O, Valdimarsdottir G and Goumans MJ: Controlling cell fate by bone morphogenetic protein receptors. Mol Cell Endocrinol 211: 105-113, 2003.

21. Wang Z, Zhang X, Shen P, Loggie BW, Chang Y and Deuel TF: A variant of estrogen receptor-\{alpha\}, hER-\{alpha\}36: transduction of estrogen- and antiestrogen-dependent membrane-initiated mitogenic signaling. Proc Natl Acad Sci USA 103: 9063-9068, 2006. 
22. Lin SL, Yan LY, Zhang XT, et al: ERalpha-36, a variant of ER-alpha, promotes tamoxifen agonist action in endometrial cancer cells via the MAPK/ERK and PI3K/Akt pathways. PLoS One 5: e9013, 2010.

23. Kipp JL, Kilen SM, Woodruff TK and Mayo KE: Activin regulates estrogen receptor gene expression in the mouse ovary. $\mathrm{J}$ Biol Chem 282: 36755-36765, 2007.

24. Shi L, Dong B, Li Z, Lu Y, Ouyang T, Li J, Wang T, Fan Z, Fan T, Lin B, Wang Z and Xie Y: Expression of ER-\{alpha\}36, a novel variant of estrogen receptor $\{a l p h a\}$, and resistance to tamoxifen treatment in breast cancer. J Clin Oncol 27: 3423-3429, 2009.

25. Lee LM, Cao J, Deng H, Chen P, Gatalica Z and Wang ZY: ER-alpha36, a novel variant of ER-alpha, is expressed in ER-positive and -negative human breast carcinomas. Anticancer Res 28: 479-483, 2008.

26. Wu L, Wu Y, Gathings B, Wan M, Li X, Grizzle W, Liu Z, Lu C, Mao Z and Cao X: Smad4 as a transcription corepressor for estrogen receptor alpha. J Biol Chem 278: 15192-15200, 2003.
27. Matsumoto Y, Otsuka F, Takano M, Mukai T, Yamanaka R, Takeda M, Miyoshi T, Inagaki K, Sada KE and Makino H: Estrogen and glucocorticoid regulate osteoblast differentiation through the interaction of bone morphogenetic protein-2 and tumor necrosis factor-alpha in $\mathrm{C} 2 \mathrm{C} 12$ cells. Mol Cell Endocrinol 325: 118-127, 2010.

28. Oreffo RO, Kusec V, Romberg S and Triffitt JT: Human bone marrow osteoprogenitors express estrogen receptor-alpha and bone morphogenetic proteins 2 and 4 mRNA during osteoblastic differentiation. J Cell Biochem 75: 382-392, 1999.

29. Zhang M, Wang Q, Yuan W, Yang S, Wang X, Yan JD, Du J, Yin J, Gao SY, Sun BC and Zhu TH: Epigenetic regulation of bone morphogenetic protein-6 gene expression in breast cancer cells. J Steroid Biochem Mol Biol 105: 91-97, 2007.

30. Yamamoto T, Saatcioglu F and Matsuda T: Cross-talk between bone morphogenic proteins and estrogen receptor signaling. Endocrinology 143: 2635-2642, 2002. 